\title{
Sanitizers Effect in Mango Pulp and Peel Antioxidant Compounds
}

\author{
Kamila de Almeida Monaco, Sergio Marques Costa, Maíra Rodrigues Uliana, \\ Giuseppina Pace Pereira Lima* \\ Department of Chemistry and Biochemistry, Institute of Biosciences, São Paulo State University (UNESP), \\ Botucatu, Brazil \\ Email: ${ }^{*}$ gpplima@ibb.unesp.br
}

Received 7 January 2014; revised 7 February 2014; accepted 14 February 2014

Copyright @ 2014 by authors and Scientific Research Publishing Inc.

This work is licensed under the Creative Commons Attribution International License (CC BY). http://creativecommons.org/licenses/by/4.0/

cC) (7) Open Access

\begin{abstract}
Effects of ozonated water as sanitizer method on mango were studied on total phenolics, flavonoids, carotenoids and vitamin $C$ of pulp or peel. Mango cultivar "Palmer" was harvested and subjected to sanitization treatments by immersion in water, chlorinated water (10 minutes sodium hypochlorite $100 \mathrm{mg} \cdot \mathrm{L}^{-1}$ ) or ozonated water for 10 and 20 minutes. After the sanitization process, the mangoes were stored at $15^{\circ} \mathrm{C} \pm 1^{\circ} \mathrm{C}$ and $85 \% \pm 5 \% \mathrm{RH}$ for seven days, followed by 4 days of storage at room temperature (simulating the trading period), totaling 11 days after harvested. Mangoes pulp sanitized with ozonated water for 20 minutes showed the highest values of TA, total soluble carbohydrates, vitamin $C$, carotenoids and flavonoid content. These data suggest that the use of ozonated water may contribute to inducing increase antioxidants compounds.
\end{abstract}

Keywords

Ozonated Water, Vitamin C, Polyphenol, Carotenoid

\section{Introduction}

Mango (Mangifera indica L.), Anacardiaceae family, is one of the most popular tropical fruits, followed by banana, pineapple, papaya and avocado. Studies about its antioxidant properties were made. This plant has parts, as the stem bark, leaves and fruit pulp, which are known for various biomedical applications, including the free radicals elimination [1] [2], anti-inflammatory [3] and anticancer [4].

Reactive oxygen species (ROS) generated during the normal metabolic processes can easily start the membrane lipid peroxidation [5]. To decrease the ROS action, plants produce substances that scavenging free radicals, de-

\footnotetext{
${ }^{*}$ Corresponding author.
} 
nominated antioxidants, which are compounds that inhibit or lag the oxidation of other molecules, inhibiting the outset or the spread of the chain oxidation reactions. Natural antioxidants are a wide range of compounds including phenolic compounds, nitrogen compounds and carotenoids [6]. Among the compounds with antioxidant action, phenolic compounds possess a series of pharmacological properties that make them active in biological systems. Several studies have been conducted evaluating their antioxidant effects, aiming chronic degenerative diseases prevention such as cardiovascular diseases, atherosclerosis, and rheumatoid arthritis, among others [7].

Furthermore, the phenolic compounds which exist mostly as esters or glycosylated forms in plants provide health benefits by several mechanisms including: free radical cleaning, protection and regeneration of others dietary antioxidants (e.g. vitamin E) and pro-oxidants metals ions chelating. However, the types and levels of phenolic compounds vary dramatically among vegetables [8].

Vegetables are usually sanitized for consumption and this step is critical and paramount importance for the microbiological quality. At this stage, it is important to check the sanitizer which should also be effective in addition to insurance toxicologically. Generally, chlorine-based compounds it is used, which may present some limitations due to the formation of some by-products such as organochlorine residues, trihalomethanes (THM) and haloacetic acids, which are mutagenic, toxic and carcinogenic. Likewise, they can remain in food, water, wash water and surfaces of food contact [9].

According to studies, some chlorinated compounds are inactivated with organic matter presence limiting their use [10]-[12]. It is believed that the hypochlorite activity losses its effectiveness after reacting with nitrogenous compounds in food, resulting in halogenated organic compounds [13] [14].

An alternative to chlorine use is the ozone. It is considered an alternative sanitizer due to its characteristics of instability and no by-products formation which may cause human health and environment issues [15] [16]. Compared to chlorine and other similar sanitizer agents, ozone needs lower concentrations and shorter food contact to an effective disinfectant action [17].

Food and Drug Administration of the United States of America (USA), recently approved the ozone as a sanitizer, applied in aqueous or gaseous forms and combined with good manufacturing practices. The US Department of Agriculture also approved this sanitizer in 1997 [16].

The aim of this study was to determine whether ozonated water use could induce increases in antioxidant compounds, contributing to obtaining mangoes "Palmer" with higher nutritional quality.

\section{Material and Methods}

Mango cultivar "Palmer" were provided by Ogata Citrus, localized in Taquaritinga, São Paulo, Brazil (latitude $21^{\circ} 37^{\prime} 11^{\prime \prime} \mathrm{S}$, longitude $49^{\circ} 04^{\prime} 25^{\prime \prime} \mathrm{W}$ and altitude 429 meters). The fruits were harvested in the early morning hours, selected, standardized in size and maturity degree and subjected to sanitization treatments by immersion in water, chlorinated water (10 minutes sodium hypochlorite $100 \mathrm{mg} \cdot \mathrm{L}^{-1}$ ) or ozonated water for 10 and $20 \mathrm{mi}-$ nutes, obtained from an ozonator (Degradatox/OZ Engenharia, Indústria de Equipamentos Geradores de OzônioLTDA, Porto Alegre, Rio Grande do Sul, Brazil). After the sanitization process, the mangoes were stored at $15^{\circ} \mathrm{C} \pm 1{ }^{\circ} \mathrm{C}$ and $85 \% \pm 5 \% \mathrm{RH}$ for seven days, followed by 4 days of storage at room temperature (simulating the trading period), totaling 11 days after harvested. The fruits were separated into pulp and peel and the analyzes were performed on fresh material. Parts of the fruit (pulp and peel) were powdered in liquid nitrogen and stored at $-80^{\circ} \mathrm{C}$, and parts oven dried at $60^{\circ} \mathrm{C} \pm 2^{\circ} \mathrm{C}$ and ground in a Willey mill. Each sanitization treatment contained 2 fruits per repetition, with four repetions, amounting 32 fruits.

It were analyzed in mango pulps soluble solide (SS), titrable acidity (TA), $\mathrm{pH}$, Vitamin C, protein, fat and total soluble carbohydrate. In the mango peel and pulps were analysed carotenoids, total polyphenolic compounds and flavonoids.

\subsection{Soluble Solids Content (SS)}

The soluble solids content were obtained by digital refractometer (ATAGO) and expressed in Brix [18].

\subsection{Titrable Acidity (TA)}

The titrable acidity was determined according to [19] and the results were expressed as malic acid equivalent in $100 \mathrm{~g}^{-1}$. 


\section{3. $\mathrm{pH}$}

For the analysis of pH (model HI 4221, Hanna Instruments Brazil), samples (10 g) were weighed and homogenized with $10 \mathrm{~mL}$ of distilled water. The $\mathrm{pH}$ value was determined by potentiometry, using $\mathrm{pH}$ buffer solution (4.01 and 7.01). Instrument calibration was carried out daily, according to [19].

\subsection{Vitamin C}

A titrimetry method was used for vitamin $\mathrm{C}$ determination by using 2,6-dichlorophenol-indophenol as indicator [19]. The results were expressed as mg vit. C $100 \mathrm{~g}^{-1}$.

\subsection{Total Protein Content}

The protein content were performed following the Kjeldahl method, the results were expressed as percentage of dry matter and calculated multiplying nitrogen percentage by a factor (6.25) [19].

\subsection{Total Soluble Carbohydrate}

The total soluble sugars were performed on the dry matter by hot extraction and the values were compared with standard glucose curve and expressed in percentage [20].

\subsection{Fat Content}

Fat were analyzed on dry matter [21] and expressed as percentage.

\subsection{Total Polyphenols}

The analysis of total polyphenols was performed in accordance to the Folin-Ciocalteu spectrophotometric method [22]. The sample material, dried and powdered, was weighed and placed into centrifuge tubes containing $50 \%$ acetone in water. The samples were incubated in an ultrasonic bath for 20 minutes and centrifuged at 6000 $\times \mathrm{g}$ (Hettich Zentrifugen, Mikro220R) for 10 minutes. The supernatants were re-extracted and combined. Folin-Ciocalteu reagent was added; after $3 \mathrm{~min}$ at $25^{\circ} \mathrm{C}$, a saturated solution of $\mathrm{Na}_{2} \mathrm{CO}_{3}$ was added, and the reaction mixture was incubated for $1 \mathrm{~h}$. The absorbance was measured at $760 \mathrm{~nm}$. Polyphenolic content was expressed as gallic acid equivalent $100 \mathrm{~g}^{-1}$.

\subsection{Total Flavonoids}

The analysis of flavonoids contents was conducted according to the spectrophotometric method adapted [23] [24], with adjustments. Briefly, fresh material samples were powdered in liquid nitrogen, weighed and mixed with $10 \%$ (w/v) acidified methanol. Subsequently, the samples were placed in an ultrasonic bath for 30 minutes, and a 5\% aluminum chloride solution was added. The samples were centrifuged for 20 minutes at 10,000 $\times g$. Finally, the samples were filtered, and the absorbance was measured at $425 \mathrm{~nm}$. The results were expressed as mangiferin meq $100 \mathrm{~g}^{-1}$.

\subsection{Total Carotenoids}

Carotenoids extraction was performed on fresh weight according to [25] method. It was based on molar absorptivity coefficient of the pigments: chlorophylls, carotenoids and anthocyanins in buffered acetone. Absorbance values were converted into mg of total carotenoids $100 \mathrm{~g}^{-1} \mathrm{FW}$ using the formulas:

$$
\begin{aligned}
& \text { Anthocyanin }\left(\mu \mathrm{mol} \cdot \mathrm{mL}^{-1}\right)=\left(0.08173 \mathrm{~A}_{537}\right)-\left(0.00697 \mathrm{~A}_{647}\right)-\left(0.002228 \mathrm{~A}_{663}\right) \\
& \text { Chlorophyll a }\left(\mu \mathrm{mol} \cdot \mathrm{mL}^{-1}\right)=0.01373\left(\mathrm{~A}_{663}\right)-0.000897\left(\mathrm{~A}_{537}\right)-0.003046\left(\mathrm{~A}_{647}\right) . \\
& \text { Chlorophyll b }\left(\mu \mathrm{mol} \cdot \mathrm{mL}^{-1}\right)=0.02405\left(\mathrm{~A}_{647}\right)-0.004305\left(\mathrm{~A}_{537}\right)-0.005507\left(\mathrm{~A}_{663}\right) . \\
& \text { Carotenoids }\left(\mu \mathrm{mol} \cdot \mathrm{mL}^{-1}\right)=\left\{\mathrm{A}_{470}-[17.1 .(\mathrm{Cla}+\mathrm{Clb})]-9.479 . \text { Anthocyanin }\right\} / 119.26 .
\end{aligned}
$$

\subsection{Statistical Analysis}

The experimental design was randomized, for the pulp analysis mean comparison test was applied (Tukey test at $5 \%$ probability). Factorial $2 \times 4$ (pulp and peel $\mathrm{x}$ sanitizations) were applied for the pulp and peel analysis. The 
software used was Statistica, 7.0 version [26].

\section{Results and Discussion}

\subsection{Pulp}

The quality parameters, SS and $\mathrm{pH}$, were not affected by the sanitizers applied (Table 1 ). The $\mathrm{pH}$ and SS values were nearby those reported by some authors [27] [28]. Sanitizer's lack of effect was also found on protein and fat contents (Table 1). Protein content of this study was lower than that detected by [29], while the fat content found is close to the described by same authors. However, the fat levels in this work were upper than reported by [30], with four varieties of mango. In this study, mangoes with 11 days after harvested and with ozone or chlorine sanitization have protein and fat levels suitable for consumption.

Regarding total soluble carbohydrate content were higher in mangoes sanitized with ozonated water. This probably means the sanitizing agent could have promoted a stress, increasing on the respiration rate, inducing the polysaccharides reserve solubilization, thereby increasing soluble carbohydrates levels, encouraging the flavor [31]. Findings were consistent with the reported increase in soluble sugar (fructose and glucose content) reported in strawberry [32] and tomato [33], in response to low-level atmospheric ozone.

Mangoes sanitized with ozonated water for 20 minutes increased their vitamin C content. Ozone is an antioxidant and vitamin $C$ has an action against oxidative stress well described [34]. In this study, the highest vitamin C content were noticed on those fruits that had the longest exposure to ozone (Table 1), and it may be a response from the vegetable cells to any injury caused by this higher exposure to the oxidant (ozone). Changes in mangoes vitamin C content were described in literature (between 5 - $194 \mathrm{mg} \cdot 100 \mathrm{~g}^{-1}$ ) [28] [29] [35].

The increase in vitamin $C$ content after the ozone use can be referred to the ozone inhibitory effect on enzymes such as ascorbate peroxidase and ascorbate oxidase (responsible for the ascorbic acid degradation), on the other hand, high ozone at damaging concentrations may reduce ascorbic acid by promoting ascorbate oxidase activity [36]. Nutritionally, increased levels of vitamin C promoted by ozonated water can be interesting for the consumer because they can get a fruit with the highest vitamin $\mathrm{C}$ content, further the benefits of a fruit with the absence of any agrochemical, as a trihalometane, produced by reactions with chlorine [12].

\subsection{Pulp and Peel}

The total carotenoid in pulp and peel (Table 2) were significantly influenced by the ozonated water use. An increase in the carotenoids content, mainly on pulp, can be observed. In tomatoes (Lycopersicum esculentum) exposed for 24 hours with ozone enriched air were also found increasing carotenoids content [37]. Studies with kiwifruit revealed that the total carotenoid content was increased after exposure to gaseous ozone (0.3 ppm) [38]. However, there are evidences decreased carotenoids levels can occurr in fresh-cut carrots after ozone exposure [39].

Total polyphenols content in "Palmer" mango pulp were not modified by the ozone use, but by chlorine which induced an increase. Chlorine is a potent sanitizer with strong oxidizing properties, generally effective, comparatively inexpensive, and the most agent used by the food industry for sanitizing products and equipment. $\mathrm{NaClO}$ in water increases $\mathrm{pH}$ and produces $\mathrm{HClO}$, which is the active disinfectant, being more efficient at a $\mathrm{pH}$ range of 6.5 - 7.5 [40]. The chlorine effect may have collaborated to promote an oxidative process, causing polyphenols increase, as a way to scavenging the ROS formation, which could damage the cells.

In this study, the flavonoids content in the pulp was much lower (14 and $24 \mathrm{mg}$ mangiferin $100 \mathrm{~g}^{-1}$ ) to that detected in three different mango cultivars (160 and 560 mg mangiferin $100 \mathrm{~g}^{-1}$ ) [41]. Otherwise the ozonated water use induced the increase of total flavonoid content in the pulp (Table 2). Polyphenols can end hazardous free radicals propagation, which causes cell lipid peroxidation by transferring an electron equivalent to radicals. Spite of the role these substances play in health maintenance, they are neglected in most food composition surveys [42]. Since ozone can induce oxidative stress in fresh fruits, which promotes many physiological responses, including the synthesis of antioxidants, polyamines, ethylene, phenolic compounds (such as flavonoids) and other secondary metabolites [43], its use as a sanitizer can be propitious for increasing the flavonoids content.

Interesting results have been obtained in mangoes peel, which presented, regardless the sanitization treatment used, higher content of these compounds that have been demonstrated potential as antioxidants. Therefore, better use of the mango peel for ingestion in food could be an excellent source of phenolic compounds. 
Table 1. Titrable acidity (TA), pH, soluble solids (SS), total soluble carbohydrate, protein and fat content in ripe and sanitized pulp of mango "Palmer".

\begin{tabular}{|c|c|c|c|c|c|}
\hline & \multicolumn{4}{|c|}{ Treatments } & \multirow[b]{2}{*}{ CV (\%) } \\
\hline & Water & Chlorine & Ozone 10 & Ozone 20 & \\
\hline $\begin{array}{c}\text { TA } \\
\text { (meq malic acid } 100 \mathrm{~g}^{-1} \text { ) }\end{array}$ & 0.88 bc & 0.82 с & $1.03 \mathrm{a}$ & $0.99 \mathrm{ab}$ & 6.15 \\
\hline pH & $4.0 \mathrm{a}$ & $4.0 \mathrm{a}$ & $4.3 \mathrm{a}$ & $4.4 \mathrm{a}$ & 4.89 \\
\hline $\begin{array}{l}\text { SS } \\
\text { (Brix) }\end{array}$ & $14.93 \mathrm{a}$ & 13.67 a & 14.73 a & 15.13 a & 4.11 \\
\hline $\begin{array}{l}\text { Carbohydrate } \\
\left(\mathrm{g} \cdot 100 \mathrm{~g}^{-1}\right)\end{array}$ & $20.56 \mathrm{c}$ & 23.57 b & $23.60 \mathrm{~b}$ & 25.67 a & 3.06 \\
\hline $\begin{array}{l}\text { Protein } \\
\left(\mathrm{g} \cdot 100 \mathrm{~g}^{-1}\right)\end{array}$ & $1.73 \mathrm{a}$ & $1.72 \mathrm{a}$ & $1.71 \mathrm{a}$ & $1.72 \mathrm{a}$ & 0.82 \\
\hline $\begin{array}{c}\text { Fat } \\
\left(\mathrm{g} \cdot 100 \mathrm{~g}^{-1}\right)\end{array}$ & $0.46 \mathrm{a}$ & $0.47 \mathrm{a}$ & $0.48 \mathrm{a}$ & $0.51 \mathrm{a}$ & 6.54 \\
\hline $\begin{array}{c}\text { Vitamin C } \\
\left(\text { mg Vit. C } 100 \mathrm{~g}^{-1} \text { ) }\right.\end{array}$ & $50.60 \mathrm{~b}$ & 53.17 b & $51.93 \mathrm{~b}$ & 64.55 a & 3.42 \\
\hline
\end{tabular}

Means followed by the same letters (row) were not statistically significant according to the Tukey’s test $(p \leq 0.05)$.

Table 2. Carotenoids, polyphenols, flavonoids contents in ripe and sanitized pulp and peel of mango "Palmer”.

\begin{tabular}{|c|c|c|c|c|c|c|}
\hline & & \multicolumn{4}{|c|}{ Treatments } & \multirow[b]{2}{*}{ CV (\%) } \\
\hline & & Water & Chlorine & Ozone 10 & Ozone 20 & \\
\hline \multirow{2}{*}{$\begin{array}{l}\text { Carotenoids } \\
\left(\mathrm{mg} \cdot 100 \mathrm{~g}^{-1}\right)\end{array}$} & pulp & $394.90 \mathrm{Ac}$ & 351.83 Ac & $751.32 \mathrm{Aa}$ & $564.84 \mathrm{Ab}$ & \multirow{2}{*}{6.15} \\
\hline & peel & $257.64 \mathrm{Bb}$ & 283.89 Bab & 337.48 Ba & 295.18 Bab & \\
\hline \multirow{2}{*}{$\begin{array}{l}\text { Polyphenols } \\
\text { (g eq. Gallic acid } 100 \mathrm{~g}^{-1} \text { ) }\end{array}$} & pulp & $0.86 \mathrm{Bb}$ & $1.07 \mathrm{Ba}$ & $0.89 \mathrm{Bb}$ & $0.93 \mathrm{Bab}$ & \multirow{2}{*}{3.70} \\
\hline & peel & $2.94 \mathrm{Aa}$ & $1.84 \mathrm{Ac}$ & $2.43 \mathrm{Ab}$ & $2.31 \mathrm{Ab}$ & \\
\hline \multirow{2}{*}{$\begin{array}{l}\text { Flavonoids } \\
\text { (meq. mangiferin } 100 \mathrm{~g}^{-1} \text { ) }\end{array}$} & pulp & 14.16 Bb & $15.08 \mathrm{Bb}$ & $25.82 \mathrm{Ba}$ & $24.50 \mathrm{Ba}$ & \multirow{2}{*}{1.87} \\
\hline & peel & 484.75 Ac & 652.14 Аа & 495.76 Ab & $594.53 \mathrm{Ab}$ & \\
\hline
\end{tabular}

Means followed by the same capital letters (column) and the same low case letters (row) were not statistically significant according to the Tukey's test $(p \leq 0.05)$.

\section{Conclusion}

The ozonated water use in mangoes "Palmer" can be profitable to increase substances with an antioxidant potential, as well as the possible consumption of the peel can be interesting for increasing the polyphenol ingestion.

\section{Acknowledgements}

The authors would like to thank FAPESP (São Paulo Research Foundation) for grating (2013/05644-3), CNPq (National Council for Scientific and Technological Development) (478372/2013-2 and 141354/2012-7) and CAPES (Coordination of Improvement of Higher Level Personnel) (2441/09-8 and 478375/2010-7).

\section{References}

[1] Ajila, C.M., Bhat, S.G. and Rao, U.J.S.P. (2007) Valuable Components of Raw and Ripe Peels from Two Indian Mango Varieties. Food Chemistry, 102, 1006-1011. http://dx.doi.org/10.1016/j.foodchem.2006.06.036

[2] Ribeiro, S.M.R., Queiroz, J.H., Queiroz, M.E.L.R., Campos, F.M. and Sant'Ana, H.M.P. (2007) Antioxidant in Mango (Mangifera indica L.) Pulp. Plant Foods for Human Nutrition, 62, 13-17. http://dx.doi.org/10.1007/s11130-006-0035-3

[3] Hernandez, P., Rodriguez, P.C., Delgado, R. and Walczak, H. (2007) Protective Effect of Mangifera indica L. Polyphenols on Human T Lymphocytes against Activation Induced Cell Death. Pharmacological Research, 55, 167-173. http://dx.doi.org/10.1016/j.phrs.2006.11.004

[4] Percival, S.S., Talcott, S.T., Chin, S.T., Mallak, A.C., Lounds-Singleton, A. and Pettit-Moore, J. (2006) Neoplastic Transformation of BALB/3T3 Cells and Cell Cycle of HL-60 Cells are Inhibited by Mango (Mangifera indica L.) Juice 
and Mango Juice Extracts. The Journal of Nutrition, 136, 1300-1304. http://dx.doi.org/10.1021/jf903161g

[5] Bergman, M., Varshavsky, L., Gottlieb, H.E. and Grossman, S. (2001) The Antioxidant Activity of Aqueous Spinach Extract: Chemical Identification of Active Fractions. Phytochemistry, 5, 143-152. http://dx.doi.org/10.1016/S0031-9422(01)00137-6

[6] Velioglu, Y.S., Mazza, G., Gao, L. and Oomah, B.D. (1998) Antioxidant activity and Total Phenolics in Selected Fruits, Vegetables, and Grain Products. Journal of Agricultural and Food Chemistry, 46, 4113-4117. http://dx.doi.org/10.1021/jf9801973

[7] Lee, S.E., Hwang, H.J., Ha, J.S., Jeong, H.S. and Kim, J.H. (2003) Screening of Medicinal Plant Extracts for Antioxidant Activity. Life Sciences, 73, 167-179. http://dx.doi.org/10.1016/S0024-3205(03)00259-5

[8] Rommel, A. and Wrolstad, R.E. (1993) Influence of Acid and Base Hydrolysis on the Phenolic Composition of Red Raspberry Juice. Journal of Agricultural and Food Chemistry, 41, 1237-1241. http://dx.doi.org/10.1021/jf00032a014

[9] Nascimento, M.S, Silva, N. and Catanozi, M.P.L.M. (2003) Emprego de Sanitizantes na Desinfecção de Vegetais. Revista Higiene Alimentar, 17, 42-46.

[10] Minear, R.A and Amy, G.L. (1995) Disinfection by-Produtcs in Water Treatment: The Chemistry of Their Formation and Control. Boca Raton, CRC Press.

[11] Richardson, S.D., Thruston, A., Caughran, T., Collette, T., Patterson, K. and Lykins, B. (1998) Chemical By-Products of Chlorine and Alternative Disinfectants. Food Technology, 52, 58-61.

[12] Rodgers, S. L., Cash, J. N., Siddiq, M. and Ryser, E.T. (2004) A Comparison of Different Chemical Sanitizers for Inactivating Escherichia coli O157:H7 and Listeria monocytogenes in Solution and on Apples, Lettuce, Strawberries, and Cantaloupe. Journal of Food Protection, 67, 721-731. http://dx.doi.org/10.1016/j.ijfoodmicro.2009.04.006

[13] Aieta, E.M., Roberts, P.V. and Hernandez, M. (1984) Determination of Chlorine Dioxide, Chlorine, Chlorite, and Chlorate in Water. Journal of the American Water Works Association, 76, 64-70.

[14] Beuchat, L.R. (1998) Surface Decontamination of Fruits and Vegetables Eaten Raw: A Review. http://dx.doi.org/10.1094/PHP-2003-0121-01-RV http://www.who.int/foodsafety/publications/fs_management/en/surface_decon.pdf

[15] Khadre, M.A. and Yousef, A.E. (2001) Sporicidal Action of Ozone and Hydrogen Peroxide: A Comparative Study. International Journal of Food Microbiology, 71, 31-138. http://dx.doi.org/10.1016/S0168-1605(01)00561-X

[16] Guzel-Seydim, Z.B., Greene, A.K. and Seydim, A.C. (2004) Use of Ozone in the Food Industry. LWT_Food Science and Technology, 37, 453-460. http://dx.doi.org/10.1016/j.lwt.2003.10.014

[17] Kim, C.K., Gentile, D.M. and Sproul, O.J. (1980) Mechanism of Ozone Inactivation of Bacteriophage F2. Applied and Environmental Microbiology, 39, 210-218.

[18] Tressler, D.J. and Joslyn, M.A. (1961) Fruits and Vegetable Juice Processing. AVI, Westport.

[19] AOAC (1995) Official Methods of Analysis. Association of Official Analytical Chemists, Arlington.

[20] Dubois, M., Gilles, K.A., Hamilton, J.K., Rebers, P.A. and Smith, F. (1956) Colorimetric Method for Determination of Sugars and Related Substances. Analytical Chemistry, 28, 350-356. http://dx.doi.org/10.1021/ac60111a017

[21] Blight, E.G. and Dyer, W.J. (1959) A Rapid Method of Total Lipid Extraction and Purification Use in Determining Vitamin E-Lipid Ratios. Canadian Journal of Biochemistry and Physiology, 37, 911-917. http://dx.doi.org/10.1139/059-099

[22] Singleton, V.L., Orthofer, R. and Lamuela-Raventos, R.M. (1999) Analysis of Total Phenols and Other Oxidation Substrates and Antioxidants by Means of Folin-Ciocalteu Reagent. In: Packer, L., Ed., Oxidants and Antioxidants, Part A, Methods in Enzymology, 299, Academic Press, New York, 152-178. http://dx.doi.org/10.1016/S0076-6879(99)99017-1

[23] Santos, M.D. and Blatt, C.T.T. (1998) Teor de Flavonóides e Fenóis Totais em Folhas de Pyrostegia Venusta Miers. de Mata e de Cerrado. Revista Brasileira de Botânica, 21, 135-140. http://dx.doi.org/10.1590/S0100-84041998000200004

[24] Awad, A.M., Jager, A.D. and Westing, L.M.V. (2000) Flavonoid and Chlorogenic Acid Levels in Apple Fruit: Characterization of Variation. Scientia Horticulturae, 83, 249-263. http://dx.doi.org/10.1016/S0304-4238(99)00124-7

[25] Sims, D.A. and Gamon, J.A. (2002) Relationships Between Leaf Pigment Content and Spectral Reflectance across a Wide Range of Species, Leaf Structures and Developmental Stages. Remote Sensing of Environment, 81, 337-354. http://dx.doi.org/10.1016/S0034-4257(02)00010-X

[26] Stat Soft Inc. (2004) Statistica (Data Analysis Software System) Version 7.0. http://www.statsoft.com

[27] Rathore, H.A., Masud, T., Sammi, S. and Majeed, S. (2010) Innovative Approach of Active Packaging in Cardboard Carton and Its Effect on Overall Quality Attributes Such as Weight Loss, Total Soluble Solids, pH, Acidity and Ascorbic Acid Contents of Chaunsa White Variety of Mango at Ambient Temperature During Storage. Pakistan Journal of Nutrition, 9, 452-458. http://dx.doi.org/10.3923/pjn.2010.452.458 
[28] Okoth, E.M., Sila, D.N., Onyango, C.A., Owino, W.O. and Musyimi, S.M. (2013) Evaluation of Chemical and Nutritional Quality Attributes of Selected Mango Varieties at Three Stages of Ripeness, Grown in Lower Eastern Province of Kenya-Part 2. Journal of Animal \& Plant Sciences, 17, 2619-2630.

[29] Sarkiyayi, S., Mohammed, M. and Yakubu, A. (2013) Comparative Analysis of Nutritional and Anti Nutritional Contents of Some Varieties of Mango (Mangifera indica) in Kaduna Metropolis-Nigeria. Advance Journal of Food Science and Technology, 5, 387-391.

[30] Kansci, G., Koubala, B.B. and Mbome, I.L. (2008) Biochemical and Physicochemical Properties of Four Mango Varieties and Some Quality Characteristics of Their Jams. Journal of Food Processing and Preservation, 32, 644-655. http://dx.doi.org/10.1111/j.1745-4549.2008.00204.x

[31] Razzaq, A., Ali, Q., Qayyum, A., Mahmood, I., Ahmad, M. and Rashid, M. (2013) Physiological Responses and Drought Resistance Index of Nine Wheat (Triticum aestivum L.) Cultivars under Different Moisture Conditions. $\mathrm{Pa}$ kistan Journal of Botany, 45, 151-155.

[32] Kute, K.M., Zhou, C. and Barth, M.M. (1995) The Effect of Ozone Exposure on Total Ascorbic Acid Activity and Soluble Solids Contents in Strawberry Tissue. Proceedings of the Annual Meeting of the Institute of Food Technologists (IFT), New Orleans, 28 January-2 February 1995, 82.

[33] Aguayo, E., Escalona, V.H. and Artés, F. (2006) Effect of Cyclic Exposure to Ozone Gas on Physicochemical, Sensorial and Microbial Quality of Whole and Sliced Tomatoes. Postharvest Biology and Technology, 39, 169-177. http://dx.doi.org/10.1016/j.postharvbio.2005.11.005

[34] Davey, M.W., Montague, M.V., Inze, D., Sanmartin, M., Kanellis, A., Smirnoff, N., Benzie, I.F.F., Strain, J.J., Favell, D. and Fletcher, J. (2000) Plant L-Ascorbic Acid: Chemistry, Function, Metabolism, Bioavailability and Effects of Processing. Journal of the Science of Food and Agriculture, 80, 825-860. http://dx.doi.org/10.1002/(SICI)1097-0010(20000515)80:7<825::AID-JSFA598>3.0.CO;2-6

[35] Sulaiman, S.F. and Ooi, K.L. (2012) Antioxidant and Anti Food-Borne Bacterial Activities of Extracts from Leaf and Different Fruit Parts of Myristica fragrans Houtt. Food Control, 25, 533-536. http://dx.doi.org/10.1016/j.foodcont.2011.11.005

[36] Ali, A., Ong, M.K. and Forney, C.F. (2014) Effect of Ozone Pre-Conditioning on Quality and Antioxidant Capacity of Papaya Fruit during Ambient Storage. Food Chemistry, 142, 19-26. http://dx.doi.org/10.1016/j.foodchem.2013.07.039

[37] Tzortzakis, N., Borland, A., Singleton, I. and Barnes, J. (2007) Impact of Atmospheric Ozone-Enrichment on QualityRelated Attributes of Tomato Frui. Postharvest Biology and Technology, 45, 317-325. http://dx.doi.org/10.1016/j.postharvbio.2007.03.004

[38] Minas, I.S., Karaoglanidis, G.S., Manganaris, G.A. and Vasilakakis, M. (2010) Effect of Ozone Application during Cold Storage of Kiwifruit on the Development of Stem-End Rot Caused by Botyris cinerea. Postharvest Biology and Technology, 58, 203-210. http://dx.doi.org/10.1016/j.postharvbio.2010.07.002

[39] Chauhan, O.P., Raju, P.S., Ravi, N., Singh, A. and Bawa, A.S. (2011) Effectiveness of Ozone in Combination with Controlled Atmosphere on Quality Characteristics Including Lignifications of Carrot Sticks. Journal of Food Engineering, 102, 43-48. http://dx.doi.org/10.1016/j.jfoodeng.2010.07.033

[40] Jemni, M., Otón, M., Ramirez, J.G., Artés-Hernández, F., Chaira, N., Ferchichi, A. and Artés, F. (2014) Conventional and Emergent Sanitizers Decreased Ectomyelois ceratoniae Infestation and Maintained Quality of Date Palm after Shelf-Life. Postharvest Biology and Technology, 87, 33-41. http://dx.doi.org/10.1016/j.postharvbio.2013.08.002

[41] Thanaraj, T. and Terry, L.A. (2009) Temporal Change in Taste-and Health-Related Compounds during Postharvest Ripening of Sri Lankan Mango Fruit (Mangifera indica L.). VI International Postharvest Symposium, Antalya, 8-12 April 2009, 1183-1189.

[42] Murillo, E., Britton, G.B. and Durant, A.A. (2012) Antioxidant Activity and Polyphenol Content in Cultivated and Wild Edible Fruits Grown in Panama. Journal of Pharmacy \& Bioallied Sciences, 4, 313-317. http://dx.doi.org/10.4103/0975-7406.103261

[43] Forney, C.F. (2003) Postharvest Response of Horticultural Products to Ozone. In: Hodges, D.M., Ed., Postharvest Oxidative Stress in Horticultural Crops, Food Products Press, New York, 13-54. 